\title{
Challenges In Developing A Digital Educational Environment
}

\author{
Mullabayev Baxtiyarjon Bulturbayevich \\ Senior Lecturer, Namangan Engineering Construction Institute \\ Associate Professor of Management, Doctor of Philosophy in Economics \\ Namangan, Republic of Uzbekistan \\ mullaboev_b@mail.ru tell: +998939486868
}

\author{
Abdul Rahmat \\ Gorontalo State University, Indonesia \\ abdulrahmat@ung.ac.id
}

Received: 12 Januari 2021; Revised: 26 Februari 2021; Accepted: 28 April 2021

DOI: http://dx.doi.org/10.37905/aksara.7.2. 247-254.2021

\begin{abstract}
The article discusses the factors that effectively shape the digital learning environment. In addition, the article details the need for the digital learning environment of the education system to be a single communication space for all participants in educational relations, an effective tool for managing the quality of educational programs, teacher performance.
\end{abstract}

Keywords: Digital education, ICT, cognitive, media resource, media library, elearning.

\section{INTRODUCTION}

The concepts of information technology and ICT are often used in one thing - methods of interacting with information and pedagogical technologies using software and hardware. The term "Digital Learning Environment" emerged in 2014 after the Manifesto of the Digital Learning Environment. Manifest Edutainme (Enjoy Education) is a non-profit initiative that brings together teachers, psychologists, designers, information architects, information technology designers and programmers. In recent years, as we know, sectors such as e-health, egovernment, e-science, e-army, e-culture and knowledge economy have really taken shape. E-learning has been incorporated into the digital society structure and is one of its key elements. However, when talking about e-learning, the main focus is, as a rule, on information technology. The rapidly evolving technological processes in the society create the conditions for the graduate of the education system to be competitive and have the characteristics that will help him to successfully adapt outside the threshold of the education system. To do this, it is necessary to create pedagogical, logistical, informational and methodological training documents that use and are used in the relevant information technology.

\section{MAIN PART}

Expected results of the implementation of the requirements of the study of information technology: 
1) increase computer literacy of all participants in the educational process (from teacher to student - 100\%);

2) increase the competitiveness of graduates of secondary special, vocational education in the labor market;

3) development of material and technical base of secondary special vocational education institutions;

4) increase the prestige of the educational institution (reports in the press and Internet publications, television and broadcast);

5) increase the prestige and attractiveness of the educational institution.

Flexibility can be achieved thanks to information technology, with a large number of data sources, maximum diversity of multimedia, and the ability to quickly and easily adapt to the student's level and needs.

The learning process, which focuses on the use of new information technology methods and organizational forms, may include:

1) individual and group work with digital learning resources (including selfmanagement and skills);

2) systematic work of students in small groups and mutual evaluation of each other's work;

3) trainings in specialized network communities (online trainings, network projects, etc.);

4) use of social services in the network for communication, collaboration on texts (in the broadest sense of the word) and storage of joint archives;

5) preparation and storage of personal learning achievements.

It was noted that the transition to a more compact system will open up new opportunities for education:

1) teachers can include fragments of other teachers' materials in their courses, give them references;

2) students can easily find information for interdisciplinary research, it will be easier to bypass their boundaries - for example, from biology to chemistry, from history to economics;

For a wide audience, including part-time students, who will continue to study all their lives, teaching will be flexible and inexpensive. The use of information technology in the classroom, as a rule, helps students to move from passive listening to active action.

There can be a number of inconveniences to this system, i.e., in addition to the benefits of reading using information technology, there can also be negative consequences.

These include:

1) negative factors of psychological and pedagogical nature;

2) physiological condition and factors that adversely affect health;

3) the absence of live communication between the participants of the learning process (teachers and students, students themselves, etc.) creates a communication in the form of "computer communication", which is:

4) creates individuality, initially weakening the creative thinking based on dialogue; 
5) students are not able to combine the knowledge they have acquired with their own hands or through real-world experience;

There are a number of other issues and problems associated with the use of communication technologies:

1) With the transition to distance learning knowledge management, identification, computer and network knowledge management programs, it becomes difficult to determine if the student himself answered all the questions correctly or if someone helped him.

2) manage data access and decide what type of training is possible;

3 ) on the equality of distance and traditional courses, diplomas, certificates, curricula, levels of distance learning in classical universities;

4) elimination of time differences in relation to large areas when conducting trainings, tests or conferences in real time;

5) communication and standards, which is especially related to the level of development of telecommunication technologies, which affects the quality of services provided and sometimes the learning process itself may be impossible. For example, if classes at a selected educational institution are conducted via videoconferencing and a modem is used to access the Internet, you may have to abandon the course you have chosen because viewing a lecture can become an impossible task. The quality of courses and programs, because, unlike traditional forms of education, the history of distance learning goes back decades, which led to the development of teaching methods, teacher training and the development of the necessary programs. not enough for.

\section{RESULTS AND DISCUSSION}

Data congestion can be an overwhelming number of emails received for reading, meditating, and responding to, and the rapid growth of databases and sites requires well-developed information management skills does.

The expediency of the use of distance learning is determined by the availability of opportunities for its development in a particular educational institution:

1) professional staff of developers in the field of information support of the distance learning process;

2) personal or licensed developments in the field of applied software as a means of supporting applied and special disciplines;

3) Sufficient material base for the organization of specialized multimedia computer classes connected to the Internet;

4) work experience of the university in correspondence and evening forms;

5) a sufficient number of applicants in the region of the university and a stable demand for specialties and areas that require admission and use of distance learning;

6) branches of the university in other regions and cities.

We should always keep in mind that distance learning, learning materials, tasks, instructions usually need to be developed more carefully than full-time 
training. The experience of distance learning has shown that a collective approach to the development and organization of the learning process in distance learning is the most sensible: teachers, specialists in the development of teaching materials and the use of different technologies, experts, editors, the joint participation of administrators, technicians, and others is required.

A complete modern training course should, as a rule, include the necessary components, in particular:

1) description of the course and schedule of various educational tasks;

2) full lecture notes (usually 10-20 lectures), including multimedia parts (audio, video, animation);

3) assignments for homework and course projects;

4) multimedia solutions for various assignments and tasks, as well as course projects;

5) samples of intermediate and final examination tasks and tests;

6) a database of frequently asked questions and answers to them;

7) electronic communications to ensure operational communication and conferences between them, such as "student-teacher", "teacher-student";

8) "electronic chat room" that allows students to work together;

9) a list of WWW addresses associated with these courses (WWW addresses of libraries of various universities offering these courses);

10) anonymous schedule of current classes of students;

11) current announcements of the electronic board;

12) means and other materials for conducting a number of audio and video conferences, such as "teacher-students".

To increase the effectiveness of distance learning methods, it is recommended to use the following recommendations:

1) a clear statement of learning goals and objectives;

2) detailed planning of student activities, its organization;

3) Increases the level of interactivity, providing electronic textbooks, e-mail, fax, audio and video conferencing, telephone communication.

4) not to allow the discussion to be based only on the textbook text;

5) formation of group harmony, use of participants and group tasks;

6) the time of students' contact with the teacher should be as long as possible and convenient for students;

7) development of the following necessary skills in students: technical, debate management, independent study, critical thinking, information management, its selection and critical evaluation;

8) use of various activities such as debates, voting, thinking and criticism;

9) use of educational contracts for formation of the purposes of participants of pedagogical process;

10) The structure of the course should be modular: the student should know exactly how it goes from module to module.

11) assist students in solving technological problems in the use of technical equipment, the use of website assistants who provide real assistance in 
establishing interactive communication between teachers and students and students;

12) the organization of active learning to achieve practical results, for example, training in small groups on the scheme of problem-solving;

13) Orient the learning process to the individual needs of the student while maintaining the integrity of the presentation.

\section{CONCLUSION}

Large amounts of information can also be distracting in the learning process.

In short, the creation of a digital learning environment using information technology necessitates the development of educational documents. Interdisciplinary communication is as important as individual areas of knowledge. The horizontal links between educational disciplines allow the development of new curricula, teaching materials. As a result, by creating flexible certification systems, it will be possible to better classify students 'knowledge and skills. The rapid development of modern society places new demands on the teaching staff. The quality of the teaching staff is the most important component of the education system, because the implementation of all other components depends directly on the personnel provided by this or that education system. The teacher himself must first and foremost have modern thinking skills, master interactive technologies, self-improvement and be a role model for students.

\section{REFERENCES}

Yakubov U.S. Ilxamova Yo.S., Jumaniyazova M.Yu. "Iqtisodiyot daax borotkompleks larivatexnologiyalari. Amaliymashg'ulotlarolibborishuchunuslubiyqo'llanma.

Axborotxavfsizligiasoslari I. M. Karimovumumiytahririostida. Ma'ruzalarkursi.

AkademikS. S. G'ulomovningumumiytahri riostida A.. Akayev, A.T.Kenjabayev, Yo.S.Ilxamova, M.Yu. Jumaniyazova Iqtisodiyotdaaxborot kompleks larivatexnologi yalari (Darslik)

http://fb.ru/article/145313/informatsionno-kommunikatsionnaya-tehnologiya-ikttehnologii

http://manifesto.edutainme.ru/

http://nvsu.ru/ru/Intellekt

Ismoilov Ravshanjon Bakhriddinovich, Mullabayev Baxtiyarjon Bultur bayevich, Mahmudova Nilufar Gulomjanovna, Usmonov Rustamjon Karimjanovich, and Bakhriddinov Jahongir Ravshanjonogli, "Use Of Modern Marketing Research In The Context Of Market Development", IEJRD - International Multidisciplinary Journal, vol. 5, no. Special Issue, p. 8, Oct. 2020.

Bulturbayevich, M. B., Saodat, S., \&Shakhnoza, N. (2020). Innovative Activity Of Small Businesses Is An Important Tool For Creating Productive JOBS. International Engineering Journal For Research \& Development, 5(6), 9-9.

Bulturbayevich, M. B., \&Jurayevich, M. B. (2020). The Impact Of The Digital Economy On Economic Growth. International Journal of Business, Law, and Education, 1(1), 4-7. Bulturbayevich, M. B., \&Jurayevich, M. B. (2020). The 
Impact Of The Digital Economy On Economic Growth. International Journal of Business, Law, and Education, 1(1), 4-7.

Jurayevich, M. B., \&Bulturbayevich, M. B. (2020). Attracting Foreign Investment In The Agricultural Economy. International Journal of Business, Law, and Education, 1(1), 1-3. Jurayevich, M. B., \&Bulturbayevich, M. B. (2020). Attracting Foreign Investment In The Agricultural Economy. International Journal of Business, Law, and Education, 1(1), 1-3.

Mamadaliyevich, S. A., Bulturbayevich, M. B., \&Shokirjonovich, A. M. (2020). Ways To Increase The Competitiveness Of National Goods In Domestic And Foreign Markets. International Engineering Journal For Research \& Development, 5(6), 6-6.

Madrahimovich, R. N., \& Bulturbayevich, M. B. (2019). Advantages of vertical integrated enterprises (under light industry enterprises). Test Engineering and Management, 81(11-12), 1596-1606.

Bulturbayevich, M. B., \&Sharipdjanovna, S. G. (2020). Improving the efficiency of management of vertical integrated industrial enterprises. TestEngineeringandManagement, 83, 5429-5440.

MullabayevBaxtiyarjonBulturbayevich, MirzabdullayevaGulnora, InamovaGuligavkhar. (2020). Analysis of Macroeconomic Indicators and Forecast of Scenarios of the Republic of Uzbekistan. International Journal of Advanced Science and Technology, 29(11s), 04 - 12. Retrieved from http://sersc.org/journals/index.php/IJAST/article/view/19921

MullabayevBaxtiyarjonBulturbayevich, InamovaGuligavkhar, UmarovaGulchekhra. (2020). Issues Of Development Of Light Industry Enterprises Through Modern Management Mechanisms And Forecasting Of Corporate Structures On The Basis Of Vertical Integration Processes. International Journal of Advanced Science and Technology, 29(11s), 1975 $1986 . \quad$ Retrieved from http://sersc.org/journals/index.php/IJAST/article/view/21866

MullabayevBaxtiyarjonBulturbayevich, SaydullaevaSaodat, JuraevaUmida, NurullaevaShakhnoza, \&ShamsievaFeruza. (2020). Mechanisms Of State Incentives For Logistics Centers To Ensure The Competitiveness Of The Economy. International Engineering Journal For Research \& Development, 5(5), 7. Retrieved from http://iejrd.com/index.php/ /article/view/1117

Ismoilov R. B., Mullabayev B. B., Abdulxakimov Z. T. Prospects For The Development Of A Tourist Route" Safed Broth Or Horn Jarir" //The American Journal of Interdisciplinary Innovations and Research. - 2020. - T. 2. - №. 08. - C. 38-44.

Ismoilov, R. B., Mullabayev, B. B., Abdulxakimov, Z. T., \&Bakhriddino, J. R. O. (2020). The Essence Of Small Business And Private Entrepreneurship And The Theoretical Basis Of Its Development. TheAmericanJournalofAppliedsciences, 2(08), 45-50.

Косимова, Д. (2020). Improvement of the strategy of vertical integration in industrial enterprises. Архив научных исследований. 
Bulturbayevich, M. B., Sharipdjanovna, S. G., Ibragimovich, A. S., \&Gulnora, M. (2020). Modern Features Of Financial Management In Small Businesses. International Engineering Journal For Research \& Development, 5(4), 5-5.

Jurayevich, M. B., \&Bulturbayevich, M. B. (2020). Attracting Foreign Investment In The Agricultural Economy. InternationalEngineeringJournalForResearch\&Development, 5 (2), 3-3.

Sobirovna, Q. D., Abdugafarovich, S. A., \&Bulturbayevich, M. B. (2019). Improvement of the strategy of vertical integration in industrial enterprises. AmericanJournalofEconomicsandBusinessManagement, 2(3), 63-68.

Mullabaev, B. B., Vohidov, E., \&Karimov, D. (2019). Role Of Vertically Integrated Enterprises In The Economy. Theoretical\&AppliedScience,(1), 85-90.

Sholdarov, D., \&Mullaboev, B. (2019). Problems of supporting financial stability of the pension supply system in Uzbekistan. Theoretical\&AppliedScience, (2), 344-349.

Mullabaev, B. B. (2018). Econometric Analysis Of Vertical Integration Of The Light Industry Enterprises Of The Namangan Region (On The Example Of The Republic Of Uzbekistan). ScientificReview: TheoryandPractice,(8), 22, 36.

Зайнутднов, Ш., \&Мллабаев, Б. (2018). Ўзбекистондаиқтисодийинтеграцияниривожлантиришваунингсамарадо рлигиниоширишомиллари. Бизнес-эксперт журнали, 30 .

Mullabayev, B. B. (2018). Economic analysis of vertical integration integration of the Namangan region (on the prerogative of the Republic of Uzbekistan). Scienceoftheory: theoryand practice"-8.

Zaynutdinov, S. N., \&Mullabayev, B. B. (2018). Regional Effectiveness Of The Regions. EconomicsandInnovativeTechnologies, 2018(1), 9.

Mullabaev, B. (2017). Development Of Light Industry Branches In Uzbekistan Based On Vertical Integration. Бюллетень науки и практики, (10), 178184.

Bachtijarzhan, M. (2017). Development Of Light Industry Branches In Uzbekistan Based On Vertical Integration. Бюллетень науки и практики, (10 (23)).

Dadaboyev, T. Y., Qoraboyev, S. A., \&Mullabaev, B. B. (2017). Corporate Management As The Factor Of Investment Attraction. Научное знание современности, (5), 77-80.

Муллабоев, Б. Б. (2015). Корпоративное управление как способ привлечения инвестиции. Молодой ученый, (10), 749-751.

Mullaboev, B. B. (2015). Corporate governance as a way to attract investment. Youngscientist, (10), 749-751. 
254 AKSARA: Jurnal Ilmu Pendidikan Nonformal 